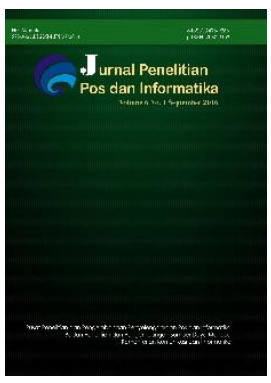

JPPI Vol 10 No 1 (2020) 27 - 40

\author{
Jurnal Penelitian Pos dan Informatika

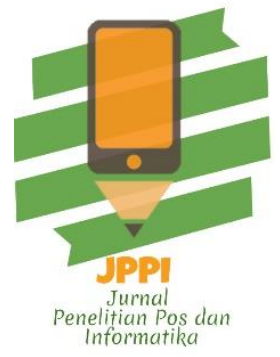

\title{
Data Governance Maturity Level at the National Archives of the Republic of Indonesia
}

\section{Tingkat Kematangan Tata Kelola Data di Arsip Nasional Republik Indonesia}

\author{
Sari Agustin Wulandari ${ }^{1}$, Yova Ruldeviyani ${ }^{2}$, Viktor Suwiyanto ${ }^{3}$, \\ Wahid Nurfiantara ${ }^{4}$, M. Alam Pasirulloh ${ }^{5}$, Mohamad Yusup Dias ${ }^{6}$
}

Faculty of Computer Science, University of Indonesia, Jl. Margonda Raya, Depok, 16424, Indonesia 123456

sari.agustin81@ui.ac.id ${ }^{l}$

Received: 7 February 2020 ; Received in revised from: 19 August 2020; Accepted: 11 September 2020

\begin{abstract}
The National Archives of the Republic of Indonesia (ANRI) as an institution mandated to carry out state duty in the field of archives has a vision as a pillar of good governance and the nation's collective memory. To implement it, a grand design of the archival system is arranged. That is closely related to data governance implementation. Therefore, it is necessary for ANRI to identify the maturity level of the data governance function which had been held. An assessment on the grand design was done by referring to the Stanford Data Governance Model. The result showed that data governance is still at an initial level. The foundational aspects are on an average of 1.2 (out of.....) which contains awareness, formalization, and metadata. While on project aspects are on average of 1.5 consisting of stewardship, data quality, and master data. In total, ANRI stands at the level of 1.35. ANRI needs to make improvements for data management planning activities referring to the Data Management Body of Knowledge (DMBOK) with a focus on people, policies, and capabilities dimensions in all aspects. This research is expected to be beneficial for ANRI to make improvements corresponding to the recommendations thus the implementation of ANRI's national data archival can be improved.
\end{abstract}

Keywords: Data Governance, Maturity Level, Stanford Data Governance, DMBOK, National Archives 


\section{INTRODUCTION}

The rapid development of technology and information requires data and information in organizations' business processes, including government organizations such as the National Archives of the Republic of Indonesia (ANRI) which is one of the Non-Ministerial Government Institutions with full authority in the field of archives (ANRI, 2009).

In realizing its vision as a pillar of good governance and a nation's collective memory integration (ANRI, 2015), ANRI compiled the Grand Design of Archival System. A Focus Group Discussion raised several critical notes on ANRI's grand design roadmap. The critical notes are closely related to ANRI's implementation data of governance within the organization. For example, in facing an electronic-based government system (SPBE) and National Archival Metadata developing, it is stated that there is a need for the sustainability of information systems that have been developed by ANRI.

The fact is that the systems are still not integrated, so the resulting data is different and does not relate to each other, and anxiety arises when the data becomes inaccurate. Therefore, data governance functions such as reference and master data management, metadata management, data architecture management, and others are very necessary to overcome these critical notes. As well as digital archives that were born from various government activities that need to be ensured handled properly. Data governance can ensure that all things are controlled within the organization (Riggins \& Klamm, 2017).
In conducting data and information management, ANRI formed The Center of Data and Information (Pusdatin) (ANRI, 2020). In 2019 until now, Pusdatin is building national archival data (DKN) includes the data on institutional archives, archival infrastructure, archival treasury, and archival human resources in Indonesia.

Therefore, it is important for ANRI to implementing data governance, preparing SPBE (Sistem Pemerintahan Berbasis Elektronik) implementation and National Archival metadata. If the data governance is not implemented, it can lead to several indicators that cause chaos such as unclean data, inconsistency, unintegrated, poor performance, low accountability, increased user dissatisfaction, and some uncontrolled things (Alruithe \& Benkhelifa, 2018).

In several previous studies, whether studies that are systematic literature review or other studies that are empirical, it is seen that many have examined data governance in financial organizations where data is an important source in the sustainability of the organization, such as research on maturity levels in securities transactions and custodians service (Yulfitri, 2020). As well as other studies that are more dominant in identifying and classifying works and data management activities within an organization (Alhassan, Sammon, \& Daly, 2016).

However, research on the application of data governance in a government agency was rarely found, especially in Indonesia. Therefore, it is important to conduct a study on the maturity of the implementation of data governance in government, especially in dealing with the implementation of SPBE. 
Even though an organization needs to have the ability to assess the implementation of data management to find out whether data management has been carried out correctly and provides appropriate results (Rivera, Loarte, Raymundo, \& Dominguez, 2017), including government organizations.

Therefore, the question in this research is, "In what level of maturity has the data governance been carried out at ANRI?"

\section{Data Governance}

Data governance is the implementation of authority and control (planning, monitoring, and implementing) for the management of the data assets (Mosley, Brackett, Earley, \& Henderson, 2009). Here are the reasons why data governance is an important thing needed in an organization (Permana \& Suroso, 2018):

1. Adjusting the data

Data adjustment is beneficial for an organization to set data format standards so that the data obtained can be easily used.

2. Improving quality in decision making

Decision making in an organization can be improved by using business intelligence (BI). Data governance can help the running of business intelligence (BI) so that decision making can be done properly. This can be done by taking the opportunity from volume growth and organization data complexity (Rivera et al, 2017).

3. Increasing user satisfaction

Data governance can help in the process of data usage because data processed using data governance has a good quality so that data is easily processed according to the needs of the organization (Wang, Lin, Chou, \& Li, 2018).

\section{Data Governance Maturity Model}

Maturity Model (MM) is a proven technique in measuring aspects of a process within an organization (Proenca \& Borbinha, 2018). Whereas, data governance is the implementation of authority and control (planning, monitoring, and implementing) for the management of data assets (Mosley et al, 2009). So that it can be concluded that the data governance maturity model is a technique for measuring a process that can be used in developing, assessing, and improving the implementation of authority and control of data assets within an organization. The level of maturity can not only help to understand the current situation, but also areas that can be developed further (Permana \& Suroso, 2018).

On the study by Proenca, 14 maturity model related to data and information management was used in the latest research (Proenca \& Borbinha, 2018). Every model is compared, there are 9 attributes as a comparison which is domain, audience, assessment method, practicality, certification, model origin, improvement opportunities prioritization, strong/weak point identification. In table 1 consists of 4 maturity models especially related to the data management domain based on research conducted by Proenca and Borbinha. Those 4 models in this research are re-filtered by the audience, assessment method, and accessibility. For the sake of this research simplification, the researcher decides using Standford Data Governance Maturity Model by consideration of assessment method conducted by way of self-assessment and audiences are 
from internal, also an assessment method can be gained freely.

Table 1. Maturity Model in Data Management Source: Proenca \& Borbinha (2018)

\begin{tabular}{|c|c|c|c|c|}
\hline Name & Description & $\begin{array}{c}\text { Au- } \\
\text { dience }\end{array}$ & $\begin{array}{l}\text { Assess- } \\
\text { ment } \\
\text { Method }\end{array}$ & $\begin{array}{l}\text { Access- } \\
\text { ibility }\end{array}$ \\
\hline $\begin{array}{l}\text { Stanford } \\
\text { Data } \\
\text { Governa } \\
\text { nce } \\
\text { Maturity } \\
\text { Model }\end{array}$ & $\begin{array}{c}\text { The } \\
\text { maturity } \\
\text { model } \\
\text { consists of } 5 \\
\text { maturity } \\
\text { levels and } \\
\text { consists of } 3 \\
\text { attributes } \\
\text { called } \\
\text { dimension. } \\
\text { This model } \\
\text { measures } \\
\text { the initial } \\
\text { aspect and } \\
\text { project } \\
\text { component } \\
\text { from the } \\
\text { data } \\
\text { governance } \\
\text { program. }\end{array}$ & Internal & $\begin{array}{c}\text { Self- } \\
\text { assessment }\end{array}$ & Free \\
\hline $\begin{array}{c}\text { CMMI } \\
\text { Institute } \\
\text { Data } \\
\text { Manage } \\
\text { ment } \\
\text { Maturity } \\
\text { Model }\end{array}$ & $\begin{array}{l}\text { There are } 5 \\
\text { maturity } \\
\text { levels and } \\
\text { attributes in } \\
2 \text { level, } 6 \\
\text { categories } \\
\text { into } 25 \\
\text { process } \\
\text { areas. }\end{array}$ & Both & $\begin{array}{c}\text { Certified } \\
\text { Profession } \\
\text { als }\end{array}$ & Charged \\
\hline $\begin{array}{c}\text { SU } \\
\text { Capabili } \\
\text { ty } \\
\text { Maturity } \\
\text { Model } \\
\text { for } \\
\text { Researc } \\
\text { h Data } \\
\text { Manage } \\
\text { ment }\end{array}$ & $\begin{array}{c}\text { Consist of } 5 \\
\text { maturity } \\
\text { levels with } \\
5 \text { main } \\
\text { process } \\
\text { areas. }\end{array}$ & Internal & $\begin{array}{c}\text { Not } \\
\text { available }\end{array}$ & Free \\
\hline $\begin{array}{l}\text { Digital } \\
\text { Asset } \\
\text { Manage } \\
\text { ment } \\
\text { Maturity } \\
\text { Model }\end{array}$ & $\begin{array}{l}\text { Consist of } 5 \\
\text { maturity } \\
\text { levels with } \\
4 \text { categories } \\
\text { and } 15 \\
\text { dimensions. }\end{array}$ & Both & $\begin{array}{c}\text { Self- } \\
\text { assessment } \\
\text {, Third- } \\
\text { party } \\
\text { Assisted }\end{array}$ & Charged \\
\hline
\end{tabular}

Stanford DG Maturity Model is chosen so that organizations can understand their strengths and weakness, as well as opportunities that exist using DMBOK. Stanford DG Maturity Model focuses on two aspects, namely foundational and project. Stanford DG Maturity Model has 3 dimensions (people, policies, and capabilities) in each aspect or component of maturity namely awareness, formalization, metadata, stewardship, data quality, and master data (Saputra, Handika, \& Ruldeviyani, 2018).

Measuring types and components, and also maturity dimension can be seen in fig. 1 (Data Governance at Stanford: The Stanford DG Maturity Model, 2011).

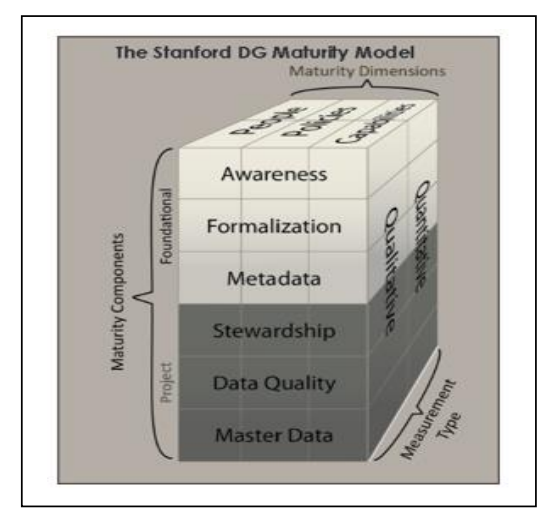

Figure 1. Stanford Data Governance Maturity Model Source: The Stanford DG Maturity Model (2011)

The maturity level measurement tool of Stanford DG uses Capability Maturity Model (CMM), which has five-level ranging from initial, managed, defined, quantitatively managed, and optimizing (Saputra et al, 2018), as shown in fig. 2.

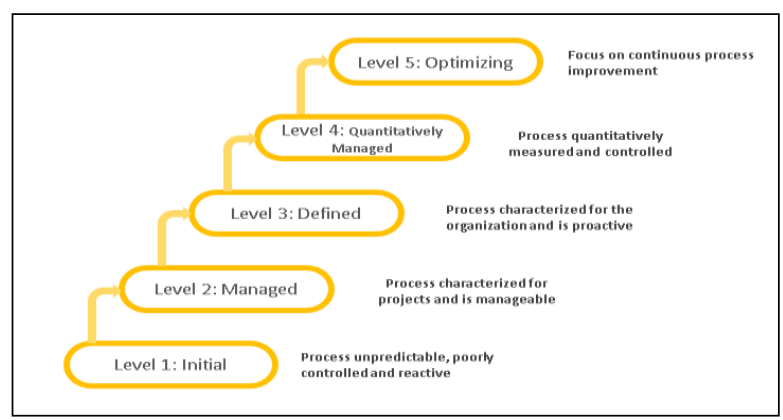

Figure 2. Characteristics of Maturity Level Source: (Permana \& Suroso, 2018)

In several previous research, many refer to DAMA International as a basic framework from DMBOK, like (Prasetyo, 2016) in his 
research wrote that DAMA International is a reference for resolve data government problems. Therefore, recommendations on activities to be adjusted to the activities in the Data Management Body of Knowledge (DMBOK).

\section{Theoretical (Conceptual) Framework}

The theoretical framework on fig. 3 begins with an organizational restructuring analysis at the Pusdatin. The Head of ANRI's decision regarding the organization's Strategic Plan and the national archival data program is implemented by Pusdatin. As well as critical notes on the study of the grand design of the archival system, maturity level measurement needs to be done by referring to the data governance using Stanford Data Governance Maturity Model in analyzing the application of data governance at ANRI, and ended with giving recommendations.

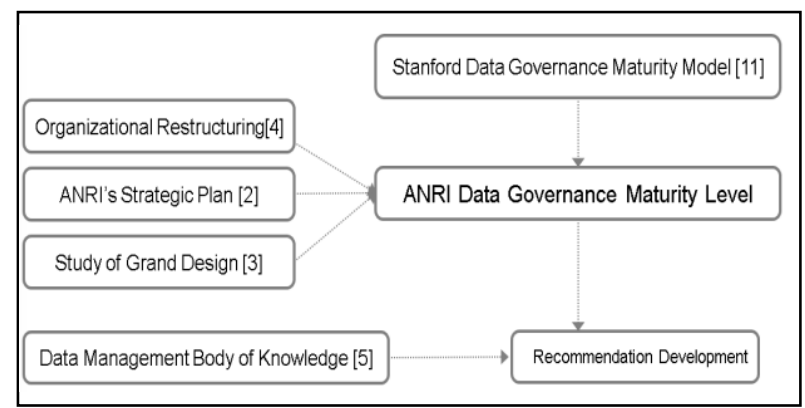

Figure 3. Theoretical (Conceptual) Framework

\section{METHODOLOGY}

The steps taken to conduct this research started with the problem analyzing, afterward conduct the literature study related to data governance and maturity model. Then conducting the assessment indicator formation. After the indicators are formed, researchers conducted the data collection, data processing, and finally developed a recommendation strategy as shown in fig. 4.

Data gathering was conducted by focus group discussion (FGD), which 6 interviewees attended from IT or archival backgrounds, specifically as human resources in the Data and Information Management Unit (Pusdatin) as the unit responsible for data and information ANRI. Data processing was done by qualitative analysis appropriate to the Stanford DG Maturity matrix.

From the FGD result, the rate of each component dimension is obtained. To obtain the maturity level of each component at the Stanford DG Maturity Model, an average calculation was made of the results of the rating dimensions of each component. Then the three components are also averaged on each aspect (foundational and project). Afterward, the analysis process is carried out as the foundation of calculation in both aspects to get the value of maturity level results and develop recommendations.

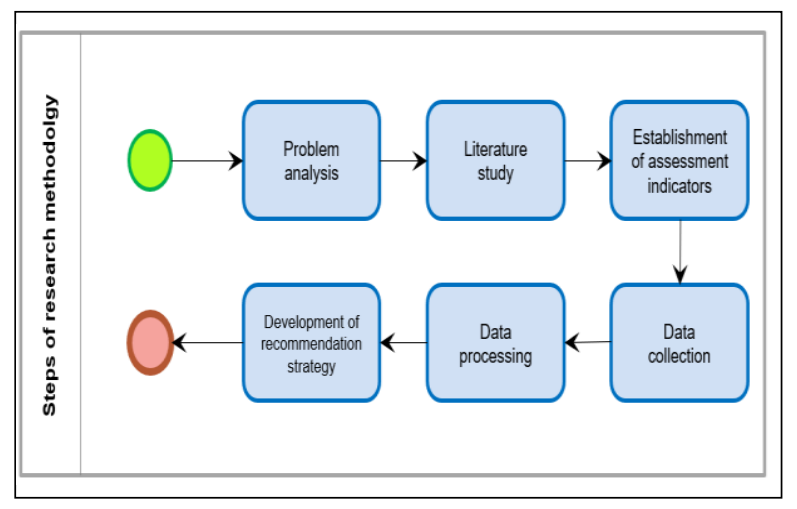

Figure 4. Methodology

\section{RESULTS AND DISCUSSION}

There is an assessment indicator for each maturity level from the research question and literature study on Stanford DG Maturity Model. 
To make it easier to conduct the assessment at ANRI's environment, the contents of each assessment indicator are translated into Indonesian and used as the basis for making questionnaires.

There are 6 assessment indicator groups at the Stanford DG Maturity Model with a range of values from the rate of 1 to rate 5 for each people, policies, and capabilities dimension, as follows ("Data Governance at Stanford: The Stanford DG Maturity Model,” 2011):

1. Indicators of assessment on foundational awareness aspect. In this people indicator, it is needed to know whether people are aware of their role in data governance. In terms of policies, it is needed to know whether policies and standards regarding data governance have been established and suited with the organization's need, and in terms of capabilities, it is needed to know whether the organization is aware of the data governance capabilities that it already has.

In other research, this indicator is the same as how an organization or individual accountability to have responsibility awareness managing data (Marchildon, Bourdeau, Hadaya, \& Labissière, 2018).

2. Indicator of assessment on foundational formalization aspect. Indicators to assess people in this aspect are needed to know things such as whether the roles and responsibilities of data governance have been determined. For assessing the policies, at what level will the data governance policies defined formally, implemented, and obeyed. Meanwhile, to be able to assess capabilities, it is needed to know how far the tools that support data governance activities are developed and how consistently they are utilized.

3. Indicators of assessment on foundational metadata aspect. In the people's dimension, it is necessary to know what level cross-unit participation in developing and maintaining metadata is. Dimensional policies, it is needed to know what level the data governance policies of creating metadata and its maintenance are formally defined and obediently implemented. For the dimensions of capabilities, data governance actively manages in the organization.

4. Indicator of assessment on project stewardship aspect. In assessing people, it is also important to know whether they are aware of their role in data governance and has been a kind of stewardship board in institutional functions. In the policies, it is important to know whether the policy regarding stewardship is by the organization's need. In capabilities, we need to know whether the capabilities of stewardship are available or not.

In another research mentioned that stewardship is how to make sure data maintenance is well set to risk mitigation and asset (Marchildon et al, 2018).

5. Indicator of assessment on project - data quality aspect. To assess the dimension of people, it is important to know whether there has been a specific role assigned to ensure data quality in a project. For the dimensions of policies, have the data governance policies defined the data quality and the dimensions of capabilities, how can the 
owned tools assess the quality of data?

In other terminology, the data quality aspect is about how data quality in producing, testing, and archiving data are measurable and improved (Marchildon et al, 2018).

6. Indicator of assessment on project - master data aspect. To assess the dimension of people, it is needed to know at what level of cross-unit participation in developing and maintaining master data. The dimension of policies is needed to know what level the master data policy been formally defined and implemented. On the capabilities side, has the organization been actively managed master data through data governance?

Within all indicators mentioned above, has covers most dimension which exists in other frameworks, such as IBM and DAMA. Those aspects include data quality, policy or formalization, and data architecture (Prasetyo, 2016), and metadata aspects (Rivera et al, 2017). There are additional indicators that Stanford has but the other data governance frameworks do not yet have, such as the awareness aspect.

\section{ANRI's Data Governance Maturity Level}

From the result of interviews during the FGD with Pusdatin's human resource, as a responsible unit for data and information at ANRI, the result of the measurement of maturity level in each component is obtained in each aspect.

1. Result of data processing

From analyzing and processing of data, the result is obtained according to the details of each aspect contained in table 2 .
Table 2. The rate for each dimension in the component

\begin{tabular}{|c|c|c|c|}
\hline \multicolumn{4}{|c|}{ FOUNDATIONAL ASPECT } \\
\hline Component & Dimension & Rating & $\begin{array}{c}\text { Rate } \\
\text { Description }\end{array}$ \\
\hline \multirow{3}{*}{ Awareness } & People & 1 & Initial \\
\hline & Policies & 1 & Initial \\
\hline & Capabilities & 2 & Managed \\
\hline \multirow{3}{*}{ Formalization } & People & 2 & Managed \\
\hline & Policies & 1 & Initial \\
\hline & Capabilities & 1 & Initial \\
\hline \multirow{3}{*}{ Metadata } & People & 1 & Initial \\
\hline & Policies & 1 & Initial \\
\hline & Capabilities & 1 & Initial \\
\hline \multicolumn{4}{|c|}{ PROJECT ASPECT } \\
\hline Component & Dimension & Rating & $\begin{array}{c}\text { Rate } \\
\text { Description }\end{array}$ \\
\hline \multirow{3}{*}{ Stewardship } & People & 2 & Managed \\
\hline & Policies & 1 & Initial \\
\hline & Capabilities & 1 & Initial \\
\hline \multirow{3}{*}{ Data Quality } & People & 1 & Initial \\
\hline & Policies & 1 & Initial \\
\hline & Capabilities & 2 & Managed \\
\hline \multirow{3}{*}{ Master Data } & People & 2 & Managed \\
\hline & Policies & 2 & Managed \\
\hline & Capabilities & 2 & Managed \\
\hline
\end{tabular}

From table 2, it is known that for foundational aspects with awareness components, people and policies dimension are still at level 1 . This is known because each person has consciously known the goals and values in the data governance but has not understood data governance itself. As with policy documentation, currently, it is incidental and data governance policies are not yet available. Ideally, data governance needs to be fully translated but in fact, in the organization of the programs and components in data governance is understanding partially. The main focus needed is on context 
creation for aligning data governance to business organization purposes (Prasetyo, 2016). In the dimensions of capabilities, the organization is at the managed level, because the organization has a special unit, Pusdatin which was established in 2015 with the issuance of the head of ANRI regulations regarding the organizational structure at the end of 2014, but other units have not consciously known the tasks and functions of Pusdatin. As well as the low awareness of other units in coordinate related to data processing in providing data as input to Pusdatin.

In the formalization component with the dimension of people in foundational aspects, it was found that the organization was at the managed level, assuming that the roles and responsibilities of data governance had been established in the legal structure, namely Pusdatin, but evaluations had not followed-up consistently. For example, in the budget provided as a form of organizational awareness in building data governance. While on the dimensions of policies and capabilities, organizations are still at the initial level because policies around data governance have not been consistently carried out every year.

The overall metadata component is still at the initial level. This is seen from the understanding of metadata is still limited, the absence of policies related to institutional metadata, and metadata still separated in each information system owned by the organization.

Meanwhile in the project aspect, with the component of stewardship and dimensions of people, the organization is at the managed level. This is because roles and responsibilities have been established but are still limited only to the scope of the Pusdatin and have not been determined by the involvement of each unit as a data provider. On dimensions of policies and capabilities, organizations are at the initial level. This indicates that policies and capabilities related to stewardship are still very limited.

The data quality component in the people and policies dimension, organizations are at the initial level with the fact that each person associated with data management has not been explicitly responsible for data quality and there is no ability to maintain data quality as a best practice to adopt in determining how good data quality. While the dimensions of capabilities are at the managed level even though data quality management is still done on an ad hoc basis.

In the master data component in the aspect of the project, the overall organization is at the managed level, where the master data has been identified, managed, and documented in the Pusdatin unit but there is no formal policy to be used institutionally at ANRI.

Overall, it can be seen, that the organization is still at the level of 1.35. This is obtained from each aspect, which is foundational 1.3 and project 1.5. The component that has been at the managed level are the master data component on the project aspect. Table 3 describes the calculation of maturity level.

Table3. Maturity level calculation result

\begin{tabular}{|c|c|c|c|c|}
\hline FOUNDATIONAL & $\begin{array}{l}\text { II } \\
0 \\
0 \\
0 \\
\frac{11}{2}\end{array}$ & 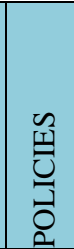 & 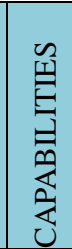 & $\begin{array}{l}\frac{1}{0} \\
\frac{\mathbb{4}}{2} \\
\frac{1}{2}\end{array}$ \\
\hline Awareness & 1 & 1 & 2 & 1.3 \\
\hline Formalization & 2 & 1 & 1 & 1.3 \\
\hline
\end{tabular}




\begin{tabular}{|c|c|c|c|c|}
\hline FOUNDATIONAL & 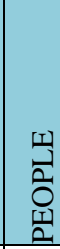 & $\begin{array}{l}\text { ص } \\
0 \\
0 \\
0 \\
0 \\
0\end{array}$ & 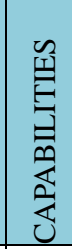 & 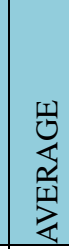 \\
\hline Metadata & 1 & 1 & 1 & 1 \\
\hline AVERAGE & 1.3 & 1 & 1.3 & 1.2 \\
\hline PROJECT & $\begin{array}{l}\frac{1}{0} \\
0 \\
0 \\
\frac{1}{2}\end{array}$ & 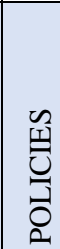 & 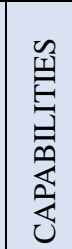 & $\begin{array}{l}\frac{1}{0} \\
\frac{\mathbb{4}}{2} \\
\frac{1}{2}\end{array}$ \\
\hline Stewardship & 2 & 1 & 1 & 1.3 \\
\hline Data Quality & 1 & 1 & 2 & 1.3 \\
\hline Master Data & 2 & 2 & 2 & 2 \\
\hline AVERAGE & 1.6 & 1.3 & 1.6 & 1.5 \\
\hline
\end{tabular}

In several previous research, data governance maturity measurement is often stopped to obtained score and only just came to the conclusion in which level organization has mature in implementing data governance. But in this research, recommendations will also be given as guidance in continuing to implement organization data governance.

\section{Recommendations}

The recommendations for improvement were developed following the characteristics of the organization as a case study. Recommendations are based on each dimension and component of the Stanford Data Governance Maturity Model, namely people, policies, and capabilities in the component of the foundation and project aspects, also on specific data management planning activity contained in the DMBOK data governance so that organization can improve. This aligns with another research that data governance is needed efforts to make sure the improvement of data management quality also reducing inaccurate data within the organization (Yulfitri, 2016).

The results of the analysis are based on the methodology and model used, it was found that the average maturity level is still at the initial level and there are needs to be some recommendations for level improvement. The result of the calculation of the level data governance maturity is the basis of the organization in knowing the weakness for improvement, as well as the strength to do enhancement related to data management. Also, as an opportunity to develop better data governance (Saputra et al, 2018). To facilitate the viewing of the organization's position, figure 5 shows the result of measuring the maturity level of data governance based on each aspect of the components.

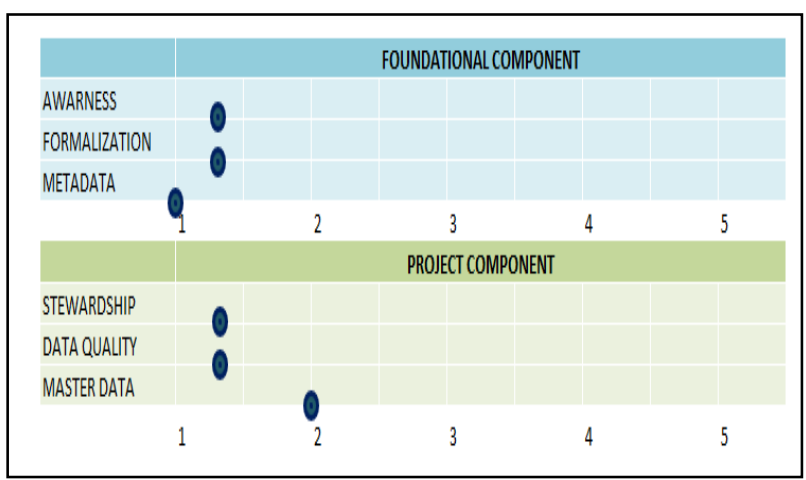

Figure 5. Organizational position in the data governance maturity level

In figure 5, it can be seen the position of the organization is still at the initial level. Where the organization is in the stage of building its data governance. The current process of managing data is still ad hoc which usually the success achieved reflects individual success rather than the process carried out stably ("Data Governance Maturity Model," 2011).

To achieve good data governance, it is necessary to adopt principles and best practices 
improving data quality and trust (Helvoirt \& Weigand, 2015). The recommendation is suggested improvements or enhancement that need to be carried out based on activities that refer to the DMBOK. Data governance can be achieved most effectively to sustain the program and continue the improvement process (Mosley et al, 2009). Each data management program can be unique considering the problems and organizational culture (Mosley et al, 2009).

Therefore, according to the characteristics of the organization, the recommendations are based on each dimension, which are people, policies, and capabilities, and on specific data management planning activities in data governance in DMBOK so that the organization can make improvements, are shown on the following table.

Table 4. Recommendations for improvements in data management planning

\begin{tabular}{|c|c|c|c|c|c|}
\hline \multicolumn{2}{|c|}{$\begin{array}{l}\text { DATA } \\
\text { MANAGEMENT } \\
\text { PLANNING }\end{array}$} & II & 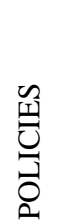 & 占 & RECOMMENDATION \\
\hline 1 & $\begin{array}{l}\text { Understand } \\
\text { strategic } \\
\text { enterprise data } \\
\text { needs }\end{array}$ & $\sqrt{ }$ & $\sqrt{ }$ & $\sqrt{ }$ & $\begin{array}{l}\text { It needs to be } \\
\text { understood and analyze } \\
\text { strategic needs in } \\
\text { national archival data }\end{array}$ \\
\hline 2 & $\begin{array}{l}\text { Develop and } \\
\text { maintain the } \\
\text { data strategy }\end{array}$ & & $\sqrt{ }$ & $\sqrt{ }$ & $\begin{array}{l}\text { Need to establish } \\
\text { strategic document as a } \\
\text { foundation of } \\
\text { implementation of } \\
\text { National Archival Data } \\
\text { (DKN) activities }\end{array}$ \\
\hline 3 & $\begin{array}{l}\text { Establish data } \\
\text { management } \\
\text { professional } \\
\text { roles and } \\
\text { organizations }\end{array}$ & $\sqrt{ }$ & $\sqrt{ }$ & $\sqrt{ }$ & $\begin{array}{l}\text { Need to establish the } \\
\text { role of each unit to } \\
\text { support DKN activities. }\end{array}$ \\
\hline 4 & $\begin{array}{l}\text { Establish data } \\
\text { governance } \\
\text { and } \\
\text { stewardship } \\
\text { organizations }\end{array}$ & $\sqrt{ }$ & & $\sqrt{ }$ & $\begin{array}{l}\text { Need further identify to } \\
\text { appoint data stewards } \\
\text { as the function of ANRI } \\
\text { and to define the ability } \\
\text { of each unit on data } \\
\text { providing. }\end{array}$ \\
\hline
\end{tabular}

\begin{tabular}{|c|c|c|c|c|c|}
\hline \multicolumn{2}{|c|}{$\begin{array}{l}\text { DATA } \\
\text { MANAGEMENT } \\
\text { PLANNING }\end{array}$} & \multirow{2}{*}{ 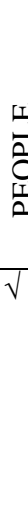 } & \multirow{2}{*}{ 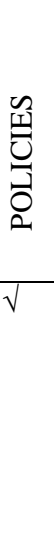 } & 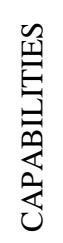 & RECOMMENDATION \\
\hline 5 & $\begin{array}{lr}\text { Identify } & \text { and } \\
\text { appoint } & \text { data } \\
\text { stewards } & \end{array}$ & & & & $\begin{array}{l}\text { Need to establish the } \\
\text { national archival data } \\
\text { governance } \\
\text { organization and its } \\
\text { implementation about } \\
\text { the data governance } \\
\text { council. }\end{array}$ \\
\hline 6 & $\begin{array}{l}\text { Develop, } \\
\text { review and } \\
\text { approve data } \\
\text { policies, } \\
\text { standards, and } \\
\text { procedures }\end{array}$ & $\sqrt{ }$ & $\sqrt{ }$ & $\sqrt{ }$ & $\begin{array}{l}\text { Need to establish } \\
\text { standard, policy, and } \\
\text { procedure related to } \\
\text { DKN which stated as a } \\
\text { reference for } \\
\text { implementation. }\end{array}$ \\
\hline 7 & $\begin{array}{l}\text { Review and } \\
\text { approve data } \\
\text { architecture }\end{array}$ & $\sqrt{ }$ & $\sqrt{ }$ & & $\begin{array}{l}\text { The need for role from } \\
\text { top management to } \\
\text { checking and approving } \\
\text { data architecture that } \\
\text { has been made. }\end{array}$ \\
\hline 8 & $\begin{array}{l}\text { Plan and } \\
\text { sponsor data } \\
\text { management } \\
\text { projects and } \\
\text { services }\end{array}$ & $\sqrt{ }$ & $\sqrt{ }$ & & $\begin{array}{l}\text { Need to establish } \\
\text { document project } \\
\text { planning documents } \\
\text { and sponsoring the } \\
\text { implementation of data } \\
\text { management services. }\end{array}$ \\
\hline$\overline{9}$ & $\begin{array}{l}\text { Estimates } \\
\text { asset value } \\
\text { and associated } \\
\text { costs }\end{array}$ & $\sqrt{ }$ & & $\sqrt{ }$ & $\begin{array}{l}\text { Need to build up the } \\
\text { consciousness to the } \\
\text { fact that data is an asset } \\
\text { for ANRI. }\end{array}$ \\
\hline
\end{tabular}

The recommendations to improve the structure of Data Governance can be seen in figure 6 :

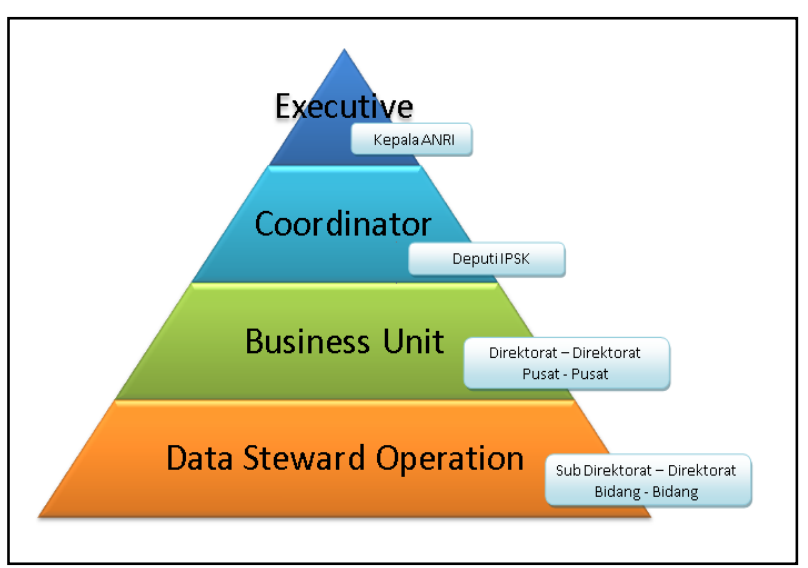

Figure 6. Proposed data governance organization

The forming of data governance is 
conducted by referring to the main task and function of each unit related to DKN activities which stated on the Organization Structure and Working Procedure (ANRI, 2020). The operation of data stewards on DKN consists of the unit as providers of data relating to institutional archiving, archival infrastructure, archival treasury, and archival human resources throughout Indonesia.

Based on recommendations for improvements and proposed data stewards, the proposal for each activity is described as follows:

1. Need to conduct a strategic requirement analysis of DKN, the results of which are used as a reference to do further activities. This is related to the awareness and ability of each person in setting organizational goals according to archival policies. This is needed as an initial initiative for the data governance policy established (Saputra et al, 2018).

2. In making strategic documents, it is necessary to establish a vision and mission, long-term goals, and steps for the success of data management related to DKN. Vision and mission are used as strategy reference and activity priority determination (Permana \& Suroso, 2018).

3. Need to determine the role of each unit relating to national archival activities as a data management service procedure. The role, responsibility, and organization culture are important criteria in developing data governance into the policy framework (Rivera et al, 2017).

4. The determination of roles is further identified in defining capabilities in each unit.

5. After the role has been established, the organization needs to be formed according to the function of managing DKN contained in the form of policies and standards.

6. The development of policies, standards, and procedures are referred to, implemented, and maintained as best practice data management for institutional data management activities in all dimensions (people, policies, and capabilities).

7. The organization establishes a data architecture regarding the activities of DKN by executive data stewards.

8. Making planning documents regarding data management includes data quality expectations, data security including confidentiality classification policies, and data access from external organizations, using data from external sources, sharing data and building data warehouses and business intelligence, and relating to unstructured data such as physical files and electronic records.

9. Data governance needs to be communicated, monitored, managed, and periodically evaluated as a form of awareness of the data's value.

Those nine recommendations were strength with the previous study about data governance maturity evaluation model in the case of the government body in South Africa, which ability improvement related to policy, people, and process have become the main factor in data governance maturity within the organization (Olaitan, Herselman, \& Wayi, 2019). 


\section{CONCLUSION}

To overcome some critical notes in the study of the national archival system for SPBE preparation, ANRI has done national archival data initiation. Therefore, it needs to be done data governance maturity level assessment.

From the result of the data governance maturity assessment, it was found that the organizational average still at the initial level with a value of 1.35 consisting of foundational aspects 1.2 and 1,5 projects. The master data in the projects were at a managed level because the Pusdatin as an authorized unit had activities regarding data management and provided master data, but was limited to certain activities where no rules were available to be used institutionally.

It is important to make improvements when ANRI has been demanded to make changes to the construction of archives and evaluation of the implementation of the strategic plan. Therefore, the recommendations proposed to relate to the basis of the development of data governance in the organization through data management planning.

This study's obstacle was less literature about the maturity model concerning the government body compared with other industries. Furthermore, this observation which is conducted was limited to Pusdatin only, therefore it is hoped for further research to conduct an analysis and observation holistically to all stakeholders related not only limited to Pusdatin. The future challenge is how to conduct more in-depth research and focus on one of the activities in the functions of data management.

\section{ACKNOWLEDGMENT}

We would like to thank Pusdatin and The Center for Archival Research and Development (Pusjibang) at ANRI and Universitas Indonesia for supporting this research.

\section{REFERENCES}

Al-ruithe, M., \& Benkhelifa, E. (2018). Determining the Enabling Factors for Implementing Cloud Data Governance in the Saudi Public Sector by Structural Equation Modelling. Future Generation Computer Systems. https://doi.org/10.1016/j.future.2017.12.057

Alhassan, I., Sammon, D., \& Daly, M. (2016). Data governance Activities: an Analysis of the Literature. Journal of Decision Systems, 25 , 64-75. https://doi.org/10.1080/12460125.2016.118 7397

ANRI. (2009). Undang-Undang No. 43 Tahun 2009 tentang Kearsipan.

ANRI. (2015). Peraturan Kepala Arsip Nasional Republik Indonesia No. 40 Tahun 2015 tentang Rencana Strategis Arsip Nasional Republik Indonesia Tahun 2015 - 2019, (7). ANRI. Peraturan Arsip Nasional Republik Indonesia Nomor 4 Tahun 2020 tentang Organisasi dan Tata Kerja Arsip Nasional Republik Indonesia (2020). https://doi.org/10.1017/CBO978110741532 4.004

Data Governance at Stanford: The Stanford DG Maturity Model. (2011).

Data Governance Maturity Model. (2011). 
Helvoirt, S. van, \& Weigand, H. (2015). Operationalizing Data Governance via Multi-level Metadata Management. IFIP International Federation for Information Processing, $\quad$ 9373, 160-172. https://doi.org/10.1007/978-3-319-25013-7

Marchildon, P., Bourdeau, S., Hadaya, P., \& Labissière, A. (2018). Data Governance Maturity assessment Tool: a Design Science Approach. Projectics / Proyéctica / Projectique (Vol. $\left.\mathrm{n}^{\circ} 20\right)$. https://doi.org/10.3917/proj.020.0155

Mosley, M., Brackett, M., Earley, S., \& Henderson, D. (2009). The DAMA Guide to The Data Management Body of Knowledge ( DAMA-DMBOK Guide ) First Edition.

Olaitan, O., Herselman, M., \& Wayi, N. (2019).

A Data Governance Maturity Evaluation Model for Government Departments of the Eastern Cape Province, South Africa. SA Journal of Information Management, 21(1), $1-12$.

https://doi.org/10.4102/sajim.v21i1.996

Permana, R. I., \& Suroso, J. S. (2018). Data Governance Maturity Assessment at PT. XYZ. Case Study: Data Management Division. Proceedings of 2018 International Conference on Information Management and Technology, ICIMTech 2018, (September), 15-20. https://doi.org/10.1109/ICIMTech.2018.852 8142

Prasetyo, H. N. (2016). A Review of Data Governance Maturity Level in Higher Education. Jitter, III(1). Retrieved from http://journal.widyatama.ac.id/index.php/jitt er/article/view/115/106
Proenca, D., \& Borbinha, J. (2018). Maturity Models for Data and Information Management. Lecture Notes in Computer Science (Including Subseries Lecture Notes in Artificial Intelligence and Lecture Notes in Bioinformatics), 2(Cmmi), 81-93. https://doi.org/10.1007/978-3-030-00066-0

Riggins, F. J., \& Klamm, B. K. (2017). Data governance Case at KrauseMcMahon LLP in an Era of Self-Service BI and Big Data. Journal of Accounting Education, 38, 2336.

https://doi.org/10.1016/j.jaccedu.2016.12.00 2

Rivera, S., Loarte, N., Raymundo, C., \& Dominguez, F. (2017). Data Governance Maturity Model for Micro Financial Organizations in Peru. ICEIS 2017 Proceedings of the 19th International Conference on Enterprise Information Systems, 3(Iceis), 203-214. https://doi.org/10.5220/0006149202030214 Saputra, D. A., Handika, D., \& Ruldeviyani, Y. (2018). Data Governance Maturity Model (DGM2) Assessment in Organization Transformation of Digital Telecommunication Company: Case Study of PT Telekomunikasi Indonesia, (1).

Wang, C. S., Lin, S. L., Chou, T. H., \& Li, B. Y. (2018). An integrated data analytics process to optimize data governance of non-profit organization. Computers in Human Behavior, 101, 495-505. https://doi.org/10.1016/j.chb.2018.10.015

Yulfitri, A. (2016). Modeling Operational Model of Data Governance in Government. 2016 International Conference on Information 
Technology Systems and Innovation, ICITSI

2016 - Proceedings, 1-5.

https://doi.org/10.1109/ICITSI.2016.785820

7

Yulfitri, A. (2020). Analisis Data Governance

Maturity Menggunakan Standford Data

Governance Maturity. BRITech (Jurnal

Ilmiah Komputer, Sains Dan Teknologi

Terapan), 1(1), 1-10. 